\title{
Regioselective preparation of tetrasubstituted alkenes from ketones using Krief's methodology as a key step for a straightforward synthesis of dienynes
}

\author{
Marc Petit, Gaëlle Chouraqui, Corinne Aubert*, and Max Malacria* \\ Université Pierre et Marie Curie-Paris 6, Laboratoire de Chimie Organique (UMR CNRS 7611), \\ Institut de Chimie Moléculaire (FR 2769), Case 229, 4 place Jussieu, \\ F-75252 Paris Cedex 05, France \\ E-mail : aubert@ccr.jussieu.fr; malacria@ccr.jussieu.fr
}

Dedicated to Professor Alain Krief on the occasion of his $65^{\text {th }}$ birthday and retirement

\begin{abstract}
Dienynes 2a-c bearing a silylated substituent ( $\left.\mathrm{SitBuMe} \mathrm{B}_{2}, \mathrm{SiMe}_{2} \mathrm{Ph}, \mathrm{Si}(\mathrm{Pr})_{3}\right)$ at the terminal position of the 1,3-butadiene moiety are highly valuable compounds as they constitute the north part of polyunsaturated precursors to the taxane framework that we have reached through $[2+2+2] /[4+2]$ cyclization strategies. They have been efficiently prepared over ten steps from the corresponding trialkylsilylchlorosilanes, the crucial step of these syntheses being the olefination of a ketone that was eventually successful via selenoacetals.
\end{abstract}

Keywords: Dienyne, selenoacetal, olefination, taxoid, [2+2+2] cyclizations

\section{Introduction}

In the past ten years, taxane diterpenoids have been one of the most challenging synthetic targets due to the unique tetracyclic structure which includes an eight-membered ring and a bridgehead double bond. They also display a high therapeutic potential. ${ }^{1}$ As a consequence, an impressive range of synthetic designs was proposed toward syntheses of taxol and its analogues; to date, six total syntheses have been reported. ${ }^{2}$

In this context and as part of our ongoing research program directed toward metal-catalyzed reactions and cascades for the elaboration of basic skeletons of natural products, ${ }^{3}$ we have recently described an approach to the taxane framework. ${ }^{4}$ Indeed, a combination of a cobalt(I)mediated $[2+2+2]$ cyclization and a [4+2] cycloaddition allows the formation of the tetracyclic skeleton of taxoids starting from highly functionalized polyunsaturated partners as depicted in Scheme 1. 


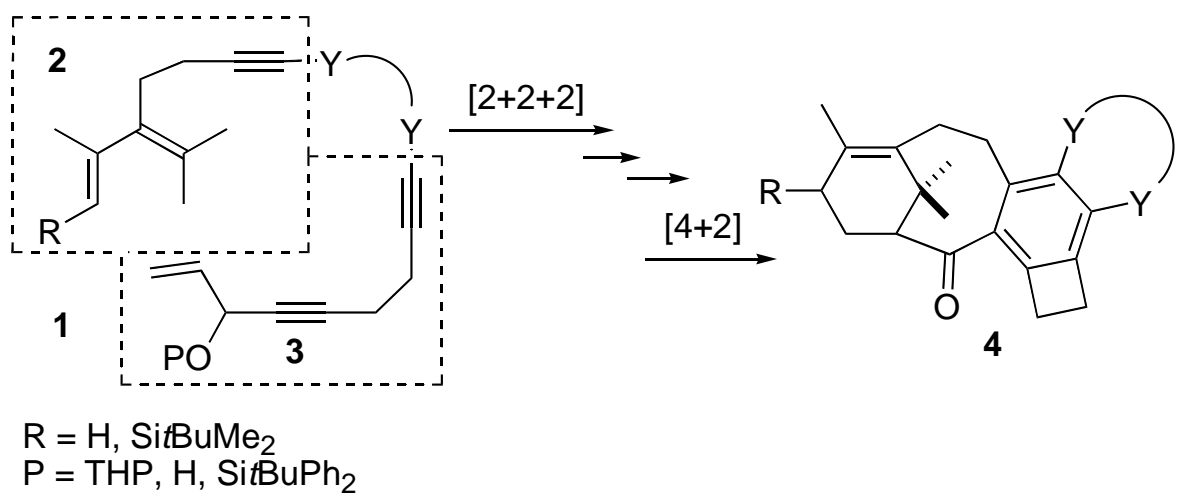

\section{Scheme 1}

The link between the two unsaturated moieties 2 and $\mathbf{3}$ can be either an alkylated $\left(-\left(\mathrm{CH}_{2}\right)_{4}-\right)$ or a silylated tether $\left(-\mathrm{O}-\mathrm{Si}(\mathrm{iPr})_{2}-\mathrm{O}_{-}\right)$which ensures the chemo- and the regioselectivity of the $[2+2+2]$ cyclizations between the three alkyne units. The success of these cycloaddition reactions was related to the presence of a sterically demanding substituent such as trialkylsilyl group at the terminal position of the 1,3-butadiene moiety which prevents some competitive cyclizations.

If the preparation of dienyne moiety 2 with $\mathrm{R}=\mathrm{SitBuMe} 2$ of the precursor $\mathbf{1}$ is now quite efficient through the use of selenoacetals described by Krief, ${ }^{5}$ it requires to adapt the reported procedures to the requisite substrates. In this paper, we report in details our efforts toward the preparation of a series of dienynes 2 .

\section{Results and Discussion}

In order to evaluate the influence of the sterical demand of the silylated substituent at the terminal position of the 1,3 butadiene moiety on the course of the cyclizations, we envisioned to prepare the dienynes 2a-c with $\mathrm{R}=\mathrm{SitBuMe} 2, \mathrm{SiMe}_{2} \mathrm{Ph}, \mathrm{Si}(\mathrm{Pr})_{3}$ starting from the corresponding E-3-trialkylsilyl-2-methyl-2-propen-1-ol 6a-c. Those were prepared following a procedure reported by our laboratory ${ }^{6}$ which consists in the sequence - generation of the silyl allyl carbanion$^{7}$ from 2-methyl-3-trialkylsilyl-prop-1-ene 5a-c prepared quantitatively from 3-chloro2-methylprop-1-ene and trialkylchlorosilane under Barbier's conditions, alkylation with dimethylchlorosilane and then chemoselective Tamao oxidation. Consecutive Swern oxidation ${ }^{8}$ furnished the aldehydes 7a-c in high overall yield. The high steric hindrance brought by $\mathrm{Si}(i \mathrm{Pr})_{3}$ did not allow a regioselective deprotonation of 5c with Schlosser's base and two inseparable allylic alcohols 6c and 6c' were obtained as a 60:40 mixture in 50\% yield (Scheme 2). 


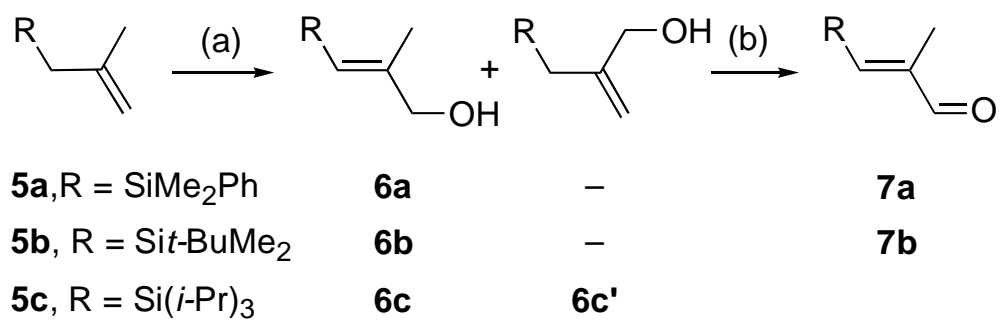

Scheme 2. (a) 1. (1/1) $t$-BuOK/n-BuLi (1.1 equiv), hexane, $0{ }^{\circ} \mathrm{C}$; $5 \mathbf{5 a}-\mathbf{c}, \mathrm{Et}_{2} \mathrm{O},-78{ }^{\circ} \mathrm{C}$ to rt; $\mathrm{ClSiMe}_{2} \mathrm{H}$ (1.1 equiv), $\mathrm{Et}_{2} \mathrm{O},-78{ }^{\circ} \mathrm{C}$. $2 . \mathrm{KHCO}_{3}$ (3 equiv), $30 \% \mathrm{H}_{2} \mathrm{O}_{2}$ in water (12 equiv), $\mathrm{MeOH}, \Delta, \mathbf{6 c} / \mathbf{6 c} \mathbf{c}^{\prime}: 50 \%$ (60:40). (b) $(\mathrm{COCl})_{2}, \mathrm{DMSO} \mathrm{NEt}_{3}, \mathrm{CH}_{2} \mathrm{Cl}_{2},-78{ }^{\circ} \mathrm{C}$ to rt, $7 \mathbf{a}: 72 \%$; $7 \mathbf{b}$ : $75 \%$ over the two steps.

In a first set of experiments carried out with aldehyde $\mathbf{7 a}$, we envisioned to introduce in a straightforward manner the triple bond and the double bond according to Scheme 3.

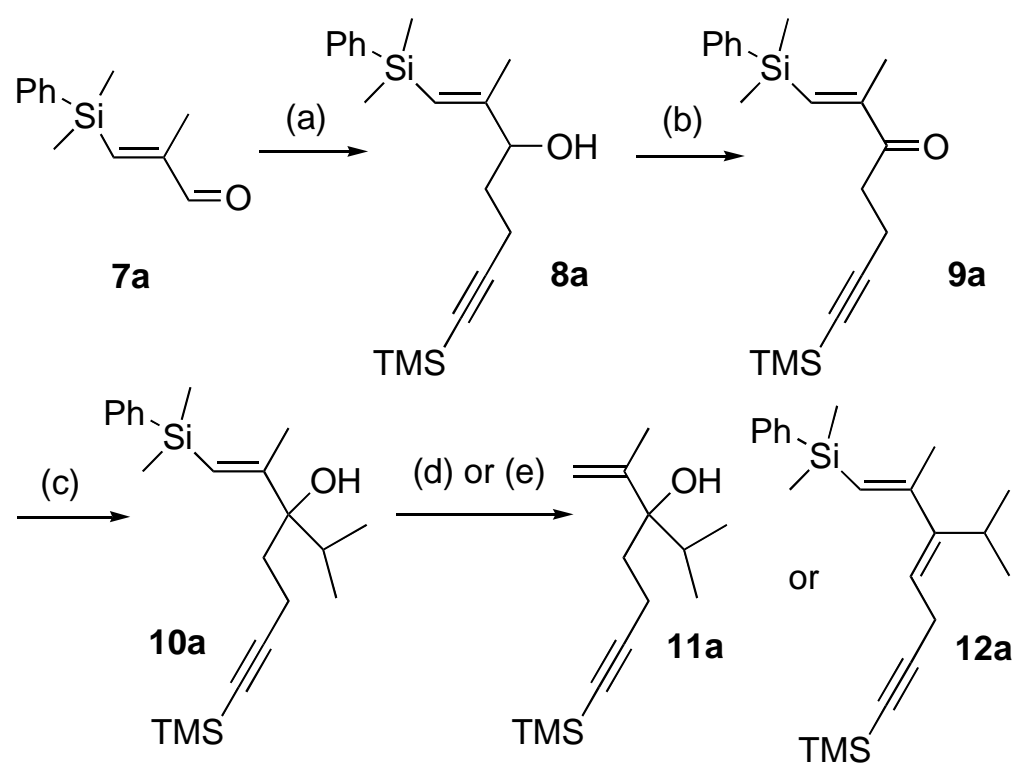

Scheme 3. (a) $1 . \mathrm{ZnCl}_{2}$ (3.3 equiv), $\mathrm{Mg}$ (4.5 equiv), $\mathrm{Me}_{3} \mathrm{SiC} \equiv \mathrm{C}\left(\mathrm{CH}_{2}\right)_{2} \mathrm{Cl}$ (3 equiv), THF, $\Delta$ then $\mathrm{CuCN}$ (6 equiv), $\mathrm{LiCl}$ (12 equiv), THF, $-20{ }^{\circ} \mathrm{C}$. 2. $7 \mathbf{7 a}, \mathrm{Et}_{2} \mathrm{O} \cdot \mathrm{BF}_{3}$ (6 equiv), -78 to $-30{ }^{\circ} \mathrm{C}, \mathbf{8 a}$ : 54\%. (b) $(\mathrm{COCl})_{2}$, DMSO, $\mathrm{NEt}_{3}, \mathrm{CH}_{2} \mathrm{Cl}_{2},-78{ }^{\circ} \mathrm{C}$ to rt, 9a: 90\%. (c) $i$-PrMgCl (1.2 equiv), HMPA (2 equiv), $\mathrm{Et}_{2} \mathrm{O}, 0^{\circ} \mathrm{C}$ to rt, 10a: $50 \%$. (d) PTSA (0.2 equiv), benzene, $\Delta$, 11a: $70 \%$. (e) $\mathrm{P}_{2} \mathrm{O}_{5}$, xylenes, $\Delta$.

Indeed, the alkylation of $\mathbf{7 a}$ with copper(I) reagent ${ }^{9}$ derived from (4-chlorobut-1ynyl)trimethylsilane prepared from the corresponding zinc derivative ${ }^{10}$ furnished in presence of $\mathrm{Et}_{2} \mathrm{O} \cdot \mathrm{BF}_{3}$, alcohol $\mathbf{8 a}$ in $54 \%$ yield; it is worthy of note that this reaction is not reproducible. Subsequent oxidation led to enone 9a in 90\% yield which was alkylated with isopropylmagnesium chloride in presence of 2 equivalents of HMPA to give tertiary alcohol 10a 
in 50\% yield beside starting material. In the absence of HMPA, the reduction of the enone occured and the secondary alcohol was obtained admixed with 10a in a 1:1 mixture. Several attempts aiming at the elimination of tertiary alcohol 10a were unsuccessful and whatever the conditions we used, we were unable to get the desired diene. Two transformations were only observed in acidic media. Indeed, in presence of PTSA in refluxing benzene or $\mathrm{Et}_{2} \mathrm{O} \cdot \mathrm{BF}_{3}$ in refluxing ether, 10a underwent a protodesilylation affording compound 11a. On the contrary, phosphorous pentoxide allowed dehydration of 10a leading to diene 12a.

Considering the above results, two issues had to be addressed : (i) the introduction of the homopropargylic chain, (ii) the olefination of the ketone. To answer to the first item, we envisaged to alkylate the aldehydes 7a-c with an alkyl chain bearing a silylated ether which could be further transformed in a simple manner into an alkyne. Thus, addition of the aldehydes 7a-b to the lithio derivative of 3-(tert-butyldimethylsilyloxy)-1-iodo propane furnished the corresponding alcohols 13a-b in $90 \%$ and $70 \%$ respectively (Scheme 4). Swern oxidation led to the enones 14a-b in very high yields. The sequence - Swern oxidation, alkylation, Swern oxidation- from the 60:40 mixture of alcohols $\mathbf{6 c}$ and $\mathbf{6} \mathbf{c}^{\prime}$ led to the corresponding enones $\mathbf{1 4 c}$ and $\mathbf{1 4} \mathbf{c}^{\prime}$ in $\mathbf{7 5 \%}$ overall yield with the same ratio.

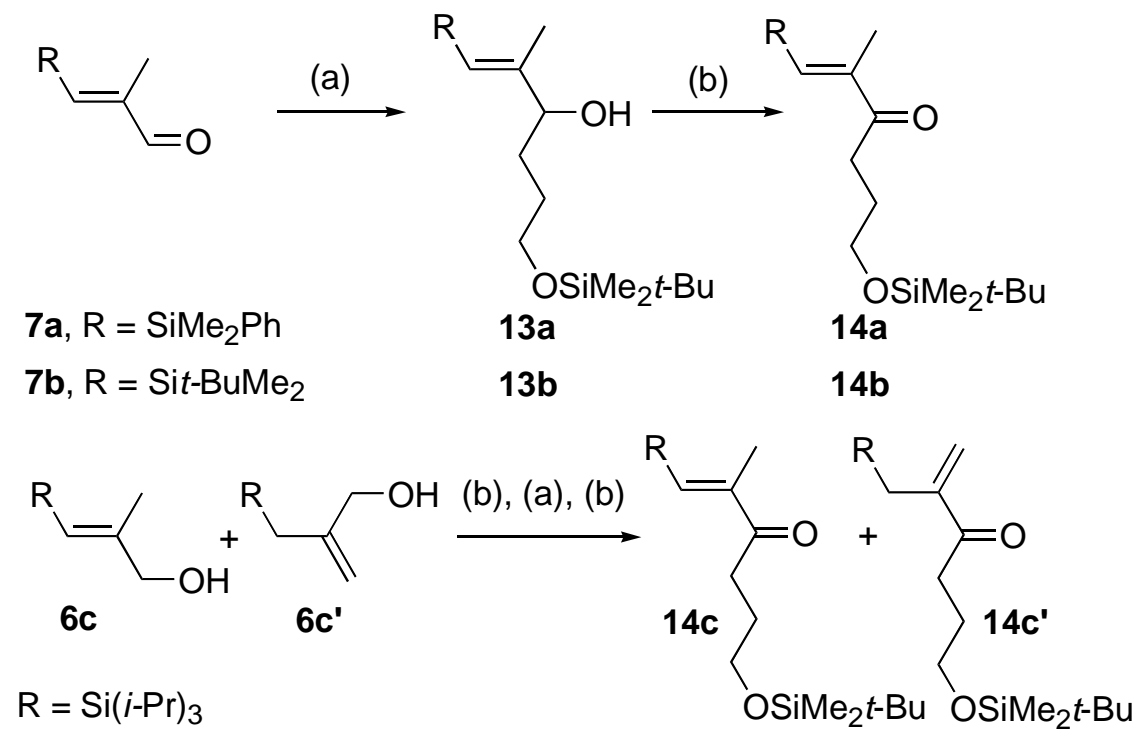

Scheme 4. (a) $t$-BuLi, $t$-BuMe ${ }_{2} \mathrm{SiO}\left(\mathrm{CH}_{2}\right)_{3} \mathrm{I},-78{ }^{\circ} \mathrm{C}$, THF, 13a: 70\%; 13b: 90\%. (b) (COCl $)_{2}$, DMSO, $\mathrm{NEt}_{3}, \mathrm{CH}_{2} \mathrm{Cl}_{2},-78{ }^{\circ} \mathrm{C}$ to rt, 14a: 66\%; 14b: 92\%; 14c/14c': 75\% over three steps.

In order to produce efficiently the tetrasubstituted double bond, we next turned our attention to 2,2-bis(methylseleno)propane. ${ }^{5,11}$ Indeed, Krief et al. has reported that such reagents can be quantitatively reduced with $n$-BuLi to the $\alpha$-selenoalkylithiums. Those are highly reactive toward aldehydes and ketones, leading to the hydroxyselenides which can be eliminated to highly substituted olefins. The use of such a reagent or its homologue 2,2bis(phenylseleno)propane has been already described by Williams ${ }^{12}$ and Jenkins ${ }^{13}$ in their 
approach to taxane model system. However, as far as we were aware, they had never been employed for the generation of a 1,3-butadiene moiety bearing a silylated group at the terminal position. Depending on the nature of the substituent on selenium, methyl versus phenyl, two procedures for the elimination of the hydroxyselenides are available. They consist in employing $\mathrm{PI}_{3}{ }^{14}$ or thionyl chloride respectively in presence of triethylamine in dichloromethane.

At the time we started this study, 2,2-bis(methylseleno)propane was commercially available but unfortunately its marketing disappeared and in spite of a generous gift from Krief's laboratory we were unable to run the whole study. Therefore, we decided to employ 2,2bis(phenylseleno)propane which was prepared according to the work of Krief with phenylselenol and acetone in presence of a Lewis acid. ${ }^{5}$ However, we slightly modified the procedure by using $\mathrm{Et}_{2} \mathrm{O} \cdot \mathrm{BF}_{3}$ in chloroform instead of $\mathrm{TiCl}_{4}$ or $\mathrm{ZnCl}_{2}$. In that case, treatment with aqueous $\mathrm{NaOH}$ and evaporation of the solvent furnished 2,2-bis(phenylseleno)propane in 81\% yield.

Whatever the reagent that we used, the olefination of the enones 14a-c were very successful and after subsequent deprotection of the silylated ethers, the dienols 15a-c were obtained in 63\% to $87 \%$ yield over three steps according to Scheme 5. It is noteworthy that the mixture of enones $\mathbf{1 4} \mathbf{c}$ and $\mathbf{1 4} \mathbf{c}^{\prime}$ was converted only into the most stable dienol 15c.

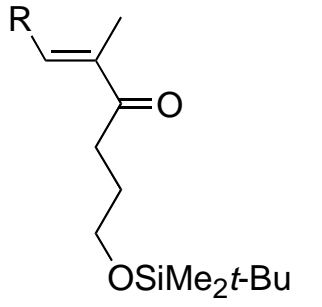

14a, $\mathrm{R}=\mathrm{SiMe}_{2} \mathrm{Ph}$

14b, $R=$ Sit-BuMe 2 (a) Method A

(b) $n$-Bu $\mathrm{B}_{4} \mathrm{NF}, \mathrm{THF}, \mathrm{rt}$

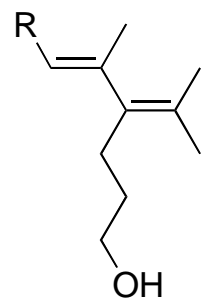

$15 a, 82 \%$

15b, 64\%

Method A: $1 . n-B u L i, \mathrm{Me}_{2} \mathrm{C}(\mathrm{SePh})_{2}, \mathrm{THF},-78^{\circ} \mathrm{C}$

2. $\mathrm{SOCl}_{2} \mathrm{NEt}_{3}, \mathrm{CH}_{2} \mathrm{Cl}_{2}$,rt

Method B: $1 . n$-BuLi, $\mathrm{Me}_{2} \mathrm{C}(\mathrm{SeMe})_{2}$, THF, $-78^{\circ} \mathrm{C}$

2. $\mathrm{PI}_{3}, \mathrm{NEt}_{3}, \mathrm{CH}_{2} \mathrm{Cl}_{2}, 0^{\circ} \mathrm{C}$

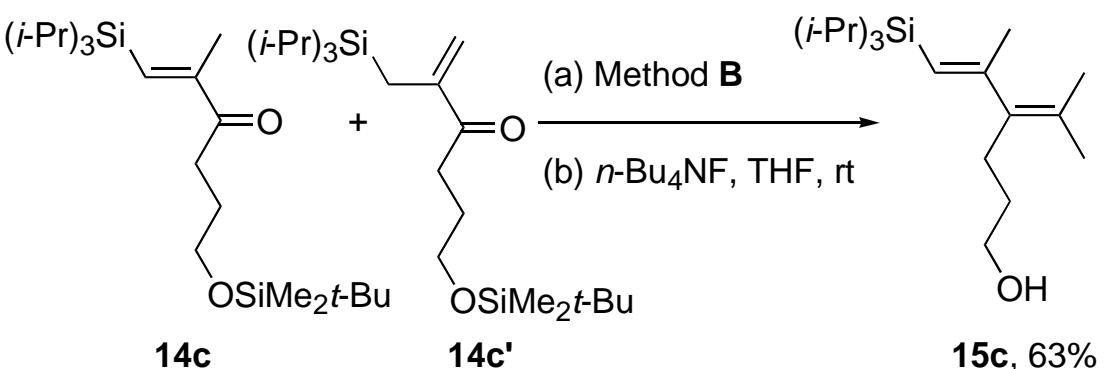

\section{Scheme 5}


After oxidation ${ }^{15}$ of $\mathbf{1 5 a - c}$, chain extension was achieved through Ohira-Bestman procedure $^{16}$ and led to the dienynes $2 \mathbf{a}-\mathbf{c}$ in $60-80 \%$ yield (Scheme 6).

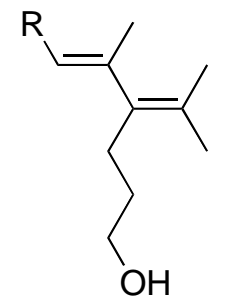

$15 \mathrm{a}, \mathrm{R}=\mathrm{SiMe}_{2} \mathrm{Ph}$

15b, R = Sit-BuMe 2

15c, $\mathrm{R}=\mathrm{Si}(i-\mathrm{Pr})_{3}$ (a) $\mathrm{SO}_{3} \cdot$ pyridine, $\mathrm{Et}_{3} \mathrm{~N}$, DMSO

(b) $\mathrm{K}_{2} \mathrm{CO}_{3}, \mathrm{MeOH}$
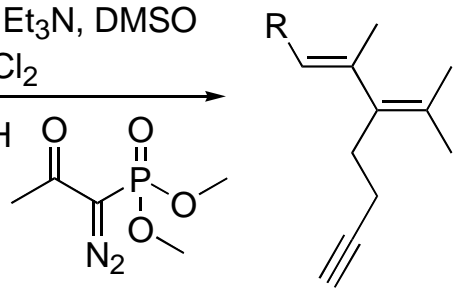

2a, $60 \%$

2b, $63 \%$

2c, $80 \%$

\section{Scheme 6}

\section{Conclusions}

In summary, we have developed an efficient preparation of dienynes 2a-c. They were obtained in ten steps from the corresponding commercially available chorosilanes in $27 \%$ overall yield (2b). This required the optimization of each step especially the olefination of the ketone which was particularly successful through the use of selenoacetals and Krief' methodology. The dienynes 2a-c are highly valuable compounds as they constitute the north part of functionalized polyunsaturated precursors to the taxane framework that we have reached through the $[2+2+2] /[4+2]$ cyclizations strategy.

\section{Experimental Section}

General Procedures. Reactions were carried out under argon in flame-dried glassware, with magnetic stirring and degassed anhydrous solvents. All commercially available reagents were used without further purification unless otherwise noted. All solvents were reagent grade and distilled under positive pressure of dry nitrogen before use. THF was distilled from sodium/benzophenone. Solid reagents were dried in vacuo (0.5 to $0.1 \mathrm{mmHg}$ ). Thin layer chromatography (TLC) was performed on Merck $60 \mathrm{~F}_{254}$ silica gel. Merck Geduran SI $60 \AA$ silica gel (35-70 $\mu \mathrm{m})$ was used for column chromatography according to Still's method. ${ }^{17} \mathrm{PE}$ and $\mathrm{EE}$ refer to petroleum ether and $\mathrm{Et}_{2} \mathrm{O}$. Chemical shifts are given in ppm, referenced to the residual proton resonances of the solvents $\left(\delta=7.26\right.$ for $\mathrm{CDCl}_{3} ; \delta=7.16$ for $\mathrm{C}_{6} \mathrm{D}_{6}$ ). Coupling constants $(J)$ are given in Hertz $(\mathrm{Hz})$. The terms $\mathrm{m}, \mathrm{s}, \mathrm{d}, \mathrm{t}, \mathrm{q}$, quint refer to multiplet, singlet, doublet, triplet, quartet, quintet; br means that the signal is broad. We use (I), (II), (III) and (IV) 
to characterize primary, secondary, tertiary and quaternary carbons. Elemental analysis were performed by the Service Régional de Microanalyse de l'Université Pierre et Marie Curie. Lowresolution mass spectra (MS) and high resolution mass spectra (HRMS) were measured by Service de spectrométrie de masse de l'ICSN-CNRS, Gif-sur-Yvette. Infrared spectra (IR) were recorded on a Bruker Tensor 27 spectrometer. Absorbance frequencies are given at maximum of intensity in $\mathrm{cm}^{-1}$.

Dimethylphenyl-(2-methyl-allyl)-silane (5a) To a suspension of $4.81 \mathrm{~g}$ of magnesium ring (148.9 mmol, 1.0 equiv) in $10 \mathrm{~mL}$ of THF was added dropwise, at room temperature, a solution of $25 \mathrm{~mL}$ of chlorodimethylphenylsilane (198.1 mmol, 1.3 equiv) and $19.3 \mathrm{~mL}$ of methylchloropropene (198.1 mmol,1.3 equiv) in $100 \mathrm{~mL}$ of THF. After the addition, the reaction mixture was heated at reflux for $12 \mathrm{~h}$. The solution was then diluted with $\mathrm{Et}_{2} \mathrm{O}$ and washed successively with a saturated solution of $\mathrm{NH}_{4} \mathrm{Cl}$ and brine, dried over $\mathrm{MgSO}_{4}$, filtered and concentrated in vacuo. The crude oil was purified by flash chromatography on silica gel (PE) and gave $5 \mathbf{a}$ as a colorless oil (28 g, quantitative). IR (neat) 3080, 2980, 1630, 1420, 1245, 1110, 725, $695 \mathrm{~cm}^{-1}-{ }^{1} \mathrm{H}$ NMR (200 MHz, $\left.\mathrm{CDCl}_{3}\right) \delta$ 7.64-7.54 (m, 2H), 7.48-7.64 (m, 3H), 4.70 (s, 1H), 4.58 (s, 1H), 1.87 (s, 2H), 1.71 (s, 3H), 0.40 (s, 6H). $\left.-{ }^{13} \mathrm{C} \mathrm{NMR} \mathrm{(50} \mathrm{MHz,} \mathrm{CDCl}_{3}\right) \delta 143.4$ (IV), 139.3 (IV), 133.8 (2C, III), 129.2 (III), 128.0 (2C, III), 109.0 (II), 27.9 (II), 25.5 (I), -2.7 (2C, I). - EIMS (m/z, \%) 152 (100), 102 (78). Anal. Calcd. for $\mathrm{C}_{12} \mathrm{H}_{18} \mathrm{Si}$ : C, 75.71; H, 9.53. Found: C, 75.39; H, 9.60.

tert-Butyl-dimethyl-(2-methyl-allyl)-silane (5b) was previously described according to reference 6

Triisopropyl-(2-methyl-allyl)-silane (5c) was prepared following the procedure described for 5a. (29.5 g, 92\%) IR (neat) 3070, 2950, 2920, 2850, 1670, 1460, 1250, $1360 \mathrm{~cm}^{-1}-{ }^{1} \mathrm{H}$ NMR $\left(400 \mathrm{MHz}, \mathrm{CDCl}_{3}\right) \delta 4.63$ (s, 2H), 1.82 (s, 3H), 1.67 (s, 2H), 1.15-1.05 (m, 21H). $-{ }^{13} \mathrm{C}$ NMR (100 MHz, $\mathrm{CDCl}_{3}$ ) $\delta 144.4$ (IV), 109.0 (II), 25.6 (I), 20.7 (II), 18.7 (6C, I), 11.8 (3C, III).

\section{3-(Dimethylphenylsilyl)-2-methyl-propenal (7a)}

1. 3-(dimethylphenylsilyl)-2-methyl-prop-2-en-1-ol (6a). To a cooled $\left(0^{\circ} \mathrm{C}\right)$ suspension of 9.19 $\mathrm{g}$ of $t$-BuOK (81.9 mmol, 1.1 equiv) in $85 \mathrm{~mL}$ of hexane were added dropwise $39 \mathrm{~mL}$ of $n$-BuLi (solution 2.1 $\mathrm{M}$ in hexane, $81.9 \mathrm{mmol}, 1.1$ equiv). The solution was stirred for $10 \mathrm{~min}$ at this temperature and then cooled to $-78{ }^{\circ} \mathrm{C}$. After dilution of the reaction mixture with $57 \mathrm{~mL}$ of $\mathrm{Et}_{2} \mathrm{O}$, a solution of $14.2 \mathrm{~g}$ of $\mathbf{5 a}$ (74.5 mmol, 1.0 equiv) in $57 \mathrm{~mL}$ of $\mathrm{Et}_{2} \mathrm{O}$ was added. Then, the mixture was warmed to room temperature and stirred for $4 \mathrm{~h}$. After being cooled to $-78{ }^{\circ} \mathrm{C}, 9.1$ $\mathrm{mL}$ of the chlorodimethyl-silane $(81.9 \mathrm{mmol}, 1.1 \mathrm{equiv})$ were added. After $1 \mathrm{~h}$, the solution was diluted with $\mathrm{Et}_{2} \mathrm{O}$ and washed successively with a saturated solution of $\mathrm{NH}_{4} \mathrm{Cl}$ and brine, dried over $\mathrm{MgSO}_{4}$, filtered and concentrated in vacuo. The resulting compound was used directly in the oxidation procedure without further purification.

To a solution of the preceding compound (74.5 mmol, 1.0 equiv) in $310 \mathrm{~mL}$ of THF and $310 \mathrm{~mL}$ of $\mathrm{MeOH}$ were added $22.4 \mathrm{~g}$ of $\mathrm{KHCO}_{3}$ (223.5 mmol, 3.0 equiv) and $22.8 \mathrm{~mL}$ of $\mathrm{H}_{2} \mathrm{O}_{2}(30 \%$ in 
water, 894.0 mmol, 12.0 equiv). After being stirred at reflux for $15 \mathrm{~min}, 22.8 \mathrm{~mL}$ of $\mathrm{H}_{2} \mathrm{O}_{2}$ were added. This last procedure was repeated twice. The mixture was filtered on a celite pad and diluted with $\mathrm{Et}_{2} \mathrm{O}$. The organic layer was successively washed with water, a saturated solution of sodium thiosulfate and brine, dried over $\mathrm{MgSO}_{4}$, filtered and concentrated in vacuo. The resulting alcohol (6a) was used directly in the next step without further purification.

2. A solution of $11.5 \mathrm{~mL}$ of dimethylsulfoxide (162.2 mmol, 2.6 equiv) in $112 \mathrm{~mL}$ of $\mathrm{CH}_{2} \mathrm{Cl}_{2}$ was added dropwise at $-78{ }^{\circ} \mathrm{C}$ to a solution of $7.1 \mathrm{~mL}$ of oxalyl chloride (81.1 mmol, 1.3 equiv) in $292 \mathrm{~mL}$ of $\mathrm{CH}_{2} \mathrm{Cl}_{2}$. After $15 \mathrm{~min}$, a solution of the preceding compound (62.4 mmol, 1.0 equiv) in $160 \mathrm{~mL}$ of $\mathrm{CH}_{2} \mathrm{Cl}_{2}$ was added slowly. After the solution was stirred at $-78{ }^{\circ} \mathrm{C}$ for 15 min, $45.1 \mathrm{~mL}$ of triethylamine (326.2 mmol, 5.2 equiv) were added. The reaction mixture was immediately warmed to room temperature, diluted with $\mathrm{Et}_{2} \mathrm{O}$, washed successively with a saturated solution of $\mathrm{NH}_{4} \mathrm{Cl}$ and brine, dried over $\mathrm{MgSO}_{4}$, filtered and concentrated in vacuo. Purification by flash chromatography (PE) furnished aldehyde 7a (11.4 g, 72\% over 3 steps). IR (neat) 3060, 2950, 2680, 1680, 1590, 1420, 725, $700 \mathrm{~cm}^{-1}-{ }^{1} \mathrm{H}$ NMR (200 MHz, $\left.\mathrm{CDCl}_{3}\right) \delta 9.48$ (s, 1H), 7.57-7.54 (m, 2H), 7.42-7.39 (m, 3H), 6.86 (d, $J=1.0 \mathrm{~Hz}, 1 \mathrm{H}), 1.84$ (d, $J=1.2 \mathrm{~Hz}, 3 \mathrm{H})$, 0.53 (s, 6H). $-{ }^{13} \mathrm{C}$ NMR (50 MHz, $\left.\mathrm{CDCl}_{3}\right) \delta 193.3$ (III), 153.4 (IV), 150.9 (III), 136.9 (IV), 133.7 (2C, III), 129.5 (III), 128.1 (2C, III), 13.6 (I), -2.0 (2C, I). - CIMS $222\left(\mathrm{MNH}_{4}{ }^{+}, 100\right), 336$ (65), 152 (45), 110 (35), 204 (M, 30).152 (100), 102 (78). - Anal. Calcd. for $\mathrm{C}_{12} \mathrm{H}_{16} \mathrm{OSi}$ : C, 70.53; H, 7.89. Found: C, 70.41; H, 8.04.

3-(tert-Butyldimethylsilyl)-2-methyl-propenal (7b). The procedure used was the same as for 7a; (7b) was previously described. ${ }^{6}$

2-Methyl-3-(triisopropylsilyl)-prop-2-en-1-ol (6c) and 2-[triisopropylsilyl)-methyl]-prop-2en-1-ol (6c') were prepared following the procedure described for (6a). (5.38 g, 50\%, inseparable 60:40 mixture of 6c:6c'). (6c) IR (neat) 3370, 2940, 2850, 1660, 1460, 1370, 1240, 830, $775 \mathrm{~cm}^{-1}-{ }^{1} \mathrm{H}$ NMR (400 MHz, $\mathrm{CDCl}_{3}$ ) $\delta 4.95$ (d, $\left.J=1.5 \mathrm{~Hz}, 1 \mathrm{H}\right), 4.80$ (d, $\left.J=1.3 \mathrm{~Hz}, 1 \mathrm{H}\right)$, 4.06 (s, 2H), 1.63 (s, 2H), 1.21 (m, 3H), 1.09 (s, 18H). $-{ }^{13} \mathrm{C}$ NMR (100 MHz, CDCl 3 ) $\delta 154.3$ (IV), 116.2, (III), 69.5 (II), 18.9 (6C, I), 18.7 (I), 12.3 (3C, III). (6c') IR (neat) 3370, 2940, 2850, 1660, 1460, 1370, 1240, 830, $775 \mathrm{~cm}^{-1}-{ }^{1} \mathrm{H}$ NMR (400 MHz, $\left.\mathrm{CDCl}_{3}\right) \delta 5.44(\mathrm{~s}, 1 \mathrm{H}), 4.06$ (s , 2H), 1.79 (s, 3H), 1.21 (m, 3H), 1.09 (s, 18H). $\left.-{ }^{13} \mathrm{C} \mathrm{NMR} \mathrm{(100} \mathrm{MHz,} \mathrm{CDCl}_{3}\right) \delta 154.3$ (IV), 107.8 (IV), 67.3 (II), 19.7 (II), 18.9 (6C, I), 11.5 (3C, III).

1-(Dimethylphenylsilyl)-2-methyl-7-(trimethylsilyl)-hept-1-en-6-yn-3-ol (8a). A $1 \mathrm{M}$ THF solution of $\mathrm{ZnCl}_{2}$ (56.1 mL, $56.1 \mathrm{mmol}, 3.3$ equiv) was added to magnesium turnings (1.83 g, $76.5 \mathrm{mmol}, 4.5$ equiv). Some drops of 1,2-dibromoethane were added followed by a slow addition of (4-chloro-but-1-ynyl)-trimethylsilane ( $8 \mathrm{~g}, 51 \mathrm{mmol}, 3$ equiv). After being heated at reflux for $4 \mathrm{~h}$ and then cooled to $-20^{\circ} \mathrm{C}$, a solution of $\mathrm{CuCN}$ (8.95 g, $100 \mathrm{mmol}, 6$ equiv) and $\mathrm{LiCl}$ (8.46 g, $200 \mathrm{mmol}, 12$ equiv) in THF (200 mL) was added to the reaction mixture. After being stirred for $15 \mathrm{~min}$, the temperature was cooled down to $-78{ }^{\circ} \mathrm{C}$ and successively, a solution of 7a (3.46 g, $17 \mathrm{mmol}, 1$ equiv) in THF (50 mL) and $\mathrm{Et}_{2} \mathrm{O} \cdot \mathrm{BF}_{3}(6.3 \mathrm{~mL}, 51 \mathrm{mmol}, 6$ equiv) were added. After being stirred for $2 \mathrm{~h}$ at $-30{ }^{\circ} \mathrm{C}$, the temperature was cooled to $-78{ }^{\circ} \mathrm{C}$ and the reaction mixture was hydrolyzed with a solution of $\mathrm{NH}_{4} \mathrm{Cl} / \mathrm{NH}_{4} \mathrm{OH}(2 / 1)$, diluted with $\mathrm{Et}_{2} \mathrm{O}$. The 
organic layer was washed successively with a saturated solution of $\mathrm{NH}_{4} \mathrm{Cl}$ and brine, dried over $\mathrm{MgSO}_{4}$, filtered and concentrated in vacuo. Purification by flash chromatography (PE/EE 8/2) furnished 8a (3.0 g, 54\%). IR (neat) 3400, 3100, 2950, 2150, 1610, 1420, 1250, 845, 735, 720 $\mathrm{cm}^{-1}-{ }^{1} \mathrm{H}$ NMR (400 MHz, $\left.\mathrm{CDCl}_{3}\right) \delta 7.51(\mathrm{~m}, 2 \mathrm{H}), 7.33(\mathrm{~m}, 3 \mathrm{H}), 5.68(\mathrm{~s}, 1 \mathrm{H}), 4.15(\mathrm{~m}, 1 \mathrm{H})$, 2.31 (m, 2H), $1.78(\mathrm{~m}, 2 \mathrm{H}), 1.68(\mathrm{~s}, 3 \mathrm{H}), 0.37$ (s, 6H), 0.15 (s, 9H) $-{ }^{13} \mathrm{C}$ NMR (100 MHz, $\mathrm{CDCl}_{3}$ ) $\delta 157.0$ (IV), 139.6 (IV), 133.6 (2C, III), 128.7 (III), 127.7 (2C, III), 120.9 (III), 106.8 (IV), 85.4 (IV), 76.9 (III), 33.9 (II), 17.6 (I), 16.4 (II), 0.0 (3C, I), -1.2 (2C, I).

1-(Dimethylphenylsilyl)-2-methyl-7-(trimethylsilyl)-hept-1-en-6-yn-3-one (9a) was prepared following Swern procedure described for (7a). Purification by flash chromatography (PE/EE 9/1) gave 9a (0.278 g, 90\%). IR (neat) 3070, 2950, 2200, 1660, 1610, $1410 \mathrm{~cm}^{-1}-{ }^{1} \mathrm{H}$ NMR (400 $\left.\mathrm{MHz}, \mathrm{CDCl}_{3}\right) \delta 7.51(\mathrm{~m}, 2 \mathrm{H}), 7.37(\mathrm{~m}, 3 \mathrm{H}), 6.78(\mathrm{~s}, 1 \mathrm{H}), 2.97(\mathrm{~m}, 2 \mathrm{H}), 2.50(\mathrm{~m}, 2 \mathrm{H}), 1.84(\mathrm{~s}$, 3H), 0.45 (s, 6H), 0.13 (s, 9H). $-{ }^{13} \mathrm{C}$ NMR (100 MHz, CDCl $) \delta 199.8$ (IV), 156.0 (IV), 138.6 (IV), 133.7 (2C, III), 128.8 (III), 127.5 (2C, III), 120.6 (III), 106.1 (IV), 84.7 (IV), 36.2 (II), 17.1 (I), 16.8 (II), 0.0 (3C, I), -1.1 (2C, I) .

1-(Dimethylphenylsilyl)-3-isopropyl-2-methyl-7-(trimethylsilyl)-hept-1-en-6-yn-3-ol (10a). To a cooled $\left(0{ }^{\circ} \mathrm{C}\right)$ solution of $9 \mathrm{a}(0.22 \mathrm{~g}, 0.67 \mathrm{mmol}, 1$ equiv) and HMPA $(0.24 \mathrm{~mL}, 1.34 \mathrm{mmol}, 2$ equiv) in THF (2 mL) was added dropwise a solution of isopropylmagnesium chloride $(0.4 \mathrm{~mL}$, 0.8 mmol, 1.2 equiv) in THF. After being stirred at room temperature until TLC had indicated completion, the reaction mixture was diluted with ether, washed successively with a saturated solution of $\mathrm{NH}_{4} \mathrm{Cl}$ and brine, dried over $\mathrm{MgSO}_{4}$, filtered and concentrated in vacuo. Purification by flash chromatography (PE/EE 9/1) furnished 10a (0.125 g, 50\%). IR (neat) 3400, 2930, 2870, 2180,1640, 1430, 1240, $910 \mathrm{~cm}^{-1}-{ }^{1} \mathrm{H}$ NMR $\left(400 \mathrm{MHz}, \mathrm{CDCl}_{3}\right) \delta 7.51(\mathrm{~m}, 2 \mathrm{H}), 7.33(\mathrm{~m}, 3 \mathrm{H})$, 5.75 (s, 1H), $2.16(\mathrm{~m}, 1 \mathrm{H}), 2.03(\mathrm{~m}, 1 \mathrm{H}), 1.92(\mathrm{~m}, 1 \mathrm{H}), 1.79(\mathrm{~m}, 1 \mathrm{H}), 1.69(\mathrm{~m}, 1 \mathrm{H}), 1.58(\mathrm{~s}, 3 \mathrm{H})$, 0.98 (m, 3H), 0.75 (m, 3H), 0.36 (s, 6H), 0.13 (s, 9H). $-{ }^{13} \mathrm{C} \mathrm{NMR}\left(100 \mathrm{MHz}, \mathrm{CDCl}_{3}\right) \delta 157.4$, (IV), 139.7 (IV), 133.6 (2C, III),128.7 (III), 127.7 (2C, III), 121.2 (III), 107.7 (IV), 85.3 (IV), 79.1 (IV), 35.4 (II), 18.9 (I), 16.9 (I), 16.1 (I), 15.1 (III), 14.9 (II), 0.0 (3C, I), -1.1 (2C, I).

3-Isopropyl-2-methyl-7-(trimethylsilyl)-hept-1-en-6-yn-3-ol (11a). A solution of 10a (0.113 g, $0.3 \mathrm{mmol}$, 1 equiv) in benzene $(1 \mathrm{~mL})$ was heated at reflux for $2 \mathrm{~h}$ in presence of paratoluenesulfonic acid (PTSA, $1 \mathrm{mg}, 0.2$ equiv) with a Dean-Stark apparatus. After being cooled at room temperature, the reaction mixture was diluted with ether, washed successively with a saturated solution of $\mathrm{NaHCO}_{3}$ and brine, dried over $\mathrm{MgSO}_{4}$, filtered and concentrated in vacuo. Purification by flash chromatography (PE/EE 9/1) gave 11a (0.05 g, 70\%). IR (neat) 3400, 2930, 2870, 2150,1640, 1430, $910 \mathrm{~cm}^{-1}-{ }^{1} \mathrm{H}$ NMR (400 MHz, $\mathrm{CDCl}_{3}$ ) $\delta 5.02$ (br s, 1H), 4.97 (br s, 1H), 2.24-2.12 (m, 4H), 1.68 (s, 3H), 1.03 (d, $J=6.6 \mathrm{~Hz}, 3 \mathrm{H}), 0.90$ (m, 1H), 0.81 (d, $J=6.6 \mathrm{~Hz}$, 3H), 0.16 (s, 9H). $-{ }^{13} \mathrm{C}$ NMR (100 MHz, $\left.\mathrm{CDCl}_{3}\right) \delta 147.1$ (IV), 127.8 (II), 112.0 (IV), 85.1 (IV), 79.7 (IV), 35.3 (II), 34.0 (II), 19.9 (I), 16.9 (I), 16.1 (I), 14.9 (III), -0.2 (3C, I).

6-(tert-Butyldimethylsilyloxy)-1-(dimethylphenylsilyl)-2-methyl-hex-1-en-3-ol (13a). To a cooled $\left(-78{ }^{\circ} \mathrm{C}\right)$ solution of $37 \mathrm{~mL}$ of THF were slowly added $100 \mathrm{~mL}$ of tert-butyllithium (solution $1.5 \mathrm{M}$ in pentane, $150.0 \mathrm{mmol}, 3.4$ equiv) and a solution of $26.2 \mathrm{~g}$ of 1-iodo-3-(tertbutyldimethylsilyloxy)-propane ( $87.2 \mathrm{mmol}, 2.0$ equiv) in $300 \mathrm{~mL}$ of THF. After being stirred 15 
min at this temperature, a solution of $8.91 \mathrm{~g}$ of compound 7a (43.6 mmol, 1.0 equiv) in $190 \mathrm{~mL}$ of THF was added. The solution was then diluted with $\mathrm{Et}_{2} \mathrm{O}$ and the organic layer was successively washed with saturated solutions of sodium thiosulfate, $\mathrm{NH}_{4} \mathrm{Cl}$ and then brine, dried over $\mathrm{MgSO}_{4}$, filtered and concentrated in vacuo. The crude oil was purified by flash chromatography on silica gel (PE/EE 9/1) affording 13a as a colorless oil (11.6 g, 70\%). IR (neat) 3300, 3030, 2950, 1600, 810, $750 \mathrm{~cm}^{-1}-{ }^{1} \mathrm{H}$ NMR (200 MHz, $\left.\mathrm{CDCl}_{3}\right) \delta$ 7.56-7.52 (m, 2H), 7.37-7.33 (m, 3H), $5.68(\mathrm{~s}, 1 \mathrm{H}), 4.06(\mathrm{t}, J=4.3 \mathrm{~Hz}, 1 \mathrm{H}), 3.67(\mathrm{t}, J=5.4 \mathrm{~Hz}, 2 \mathrm{H}), 1.69$ (s, 3H), $1.64-1.59$ (m, 2H), 0.92 (s, 9H), 0.89-0.84 (m, 2H), 0.38 (s, 6H), $0.08(\mathrm{~s}, 6 \mathrm{H}) .-{ }^{13} \mathrm{C}$ NMR (50 MHz, $\mathrm{CDCl}_{3}$ ) $\delta 158.2$ (IV), 139.8 (IV), 133.8 (2C, III), 128.8 (III), 127.8 (2C, III), 120.4 (III), 78.0 (III), 63.5 (III), 32.6 (III), 28.9 (III), 26.0 (3C, I), 18.4 (IV), 17.9 (I), -0.9 (2C, I), -5.2 (2C, I). - Anal. Calcd. for $\mathrm{C}_{21} \mathrm{H}_{38} \mathrm{O}_{2} \mathrm{Si}_{2}$ : C, 66.6; H, 10.11. Found: C, 66.5; H, 10.16.

1-(tert-Butyldimethylsilyl)-6-(tert-butyldimethylsilyloxy)-2-methyl-hex-1-en-3-ol (13b) was prepared following the procedure described for 13a (3.32 g, 90\%). IR (neat) 3320, 3030, 2950, 1600, 1230, 810, $750 \mathrm{~cm}^{-1}-{ }^{1} \mathrm{H}$ NMR (400 MHz, $\left.\mathrm{CDCl}_{3}\right) \delta 5.55$ (s, 1H), 4.03 (t, $\left.J=5.2 \mathrm{~Hz}, 1 \mathrm{H}\right)$, 3.66 (t, $J=5.6 \mathrm{~Hz}, 2 \mathrm{H}), 1.77$ (s, 3H), 1.69-1.56 (m, 4H), 0.91 (s, 9H), 0.87 (s, 9H), 0.10 (s, 6H), 0.07 (s, 6H). $-{ }^{13} \mathrm{C}$ NMR (100 MHz, $\mathrm{CDCl}_{3}$ ) $\delta 157.0$ (IV), 120.3 (III), 78.6 (III), 63.4 (II), 32.4 (II), 28.9 (II), 26.5 (3C, I), 26.0 (3C, I), 18.4 (IV), 17.5 (I), 17.3 (IV), -4.2 (2C, I), -5.3 (2C, I). Anal. Calcd. for $\mathrm{C}_{19} \mathrm{H}_{42} \mathrm{O}_{2} \mathrm{Si}_{2}$ : C, 63.62; H, 11.80. Found: C, 63.60; H, 11.78 .

6-(tert-butyldimethylsilyloxy)-1-(dimethylphenylsilyl)-2-methyl-hex-1-en-3-one (14a) was prepared following Swern procedure described above for 7a; (5.06 g, 66\%). IR (neat) 3030, 2980,1690,1670, 1250, 1100, 835, $715 \mathrm{~cm}^{-1}-{ }^{1} \mathrm{H}$ NMR (200 MHz, $\left.\mathrm{CDCl}_{3}\right) \delta$ 7.54-7.53 (m, 2H), 7.39-7.36 (m, 3H), 6.82 (s, 1H), 3.65 (t, $J=5.9 \mathrm{~Hz}, 2 \mathrm{H}), 2.83$ (t, $J=7.4 \mathrm{~Hz}, 2 \mathrm{H}), 1.87-1.86$ (m, 5H), 0.90 (s, 9H), 0.47 (s, 6H), 0.05 (s, 6H). $\left.-{ }^{13} \mathrm{C} \mathrm{NMR} \mathrm{(50} \mathrm{MHz,} \mathrm{CDCl}_{3}\right) \delta 202.3$ (IV), 152.8 (IV), 137.8 (IV), 137.4 (III), 133.8 (2C, III), 129.4 (III), 128.1 (2C, III), 62.3 (II), 33.4 (II), 27.7 (II), 26.0 (3C, I), 18.4 (IV), 17.1 (I), -1.5 (2C, I), -5.2 (2C, I). - EIMS (m/z, \%) 377 ( $\left.\mathrm{MH}^{+}, 100\right)$, 245 (25), 152 (15). - Anal. Calcd. for $\mathrm{C}_{21} \mathrm{H}_{36} \mathrm{O}_{2} \mathrm{Si}_{2}$ : C, 66.96; H, 9.63. Found: C, 66.84; H, 10.00. 1-(tert-Butyldimethylsilyl)-6-(tert-butyldimethylsilyloxy)-2-methyl-hex-1-en-3-one (14b) was prepared following Swern procedure described above for 7a; (1.85 g, 92\%). IR (neat) 3030, 2980, 1685, 1665, 1250, 1100, 835, $715 \mathrm{~cm}^{-1}-{ }^{1} \mathrm{H}$ NMR (400 MHz, $\left.\mathrm{CDCl}_{3}\right) \delta 6.70(\mathrm{~s}, 1 \mathrm{H}), 3.63$ (t, $J=6.0 \mathrm{~Hz}, 2 \mathrm{H}), 2.79$ (t, $J=7.6 \mathrm{~Hz}, 2 \mathrm{H}), 1.92$ (s, 3H), 1.81 (qt, $J=6.0,7.2 \mathrm{~Hz}, 2 \mathrm{H}), 0.92$ (s, 9H), 0.88 (s, 9H), 0.35 (s, 6H), 0.16 (s, 6H). $-{ }^{13} \mathrm{C}$ NMR (50 MHz, $\left.\mathrm{CDCl}_{3}\right) \delta 202.3$ (IV), 152.3 (IV), 137.2 (III), 62.3 (II), 33.5 (II), 27.8 (II), 26.5 (3C, I), 26.0 (3C, I), 18.4 (IV), 17.2 (IV), 17.0 (I), -4.7 (2C, I), -5.3 (2C, I).

6-(tert-Butyldimethylsilyloxy)-2-methyl-1-(triisopropylsilyl)-hex-1-en-3-one (14c) and 6(tert-Butyldimethylsilyloxy)-2-[(triisopropylsilyl)-methyl]-hex-1-en-3-one $\quad\left(14 c^{\prime}\right) \quad$ were prepared from the 60:40 mixture of $\mathbf{6 c} / \mathbf{6} \mathbf{c}^{\prime}$ following the sequence - Swern oxidation, alkylation, Swern oxidation- and the procedures described above for 7a and 13a. (1.60 g, 75\% over three steps). (14c) IR (neat) 3030, 2980, 1685, 1665, 1250, 1100, 835, $715 \mathrm{~cm}^{-1}-{ }^{1} \mathrm{H}$ NMR (400 MHz, $\left.\mathrm{CDCl}_{3}\right) \delta 6.68(\mathrm{~s}, 1 \mathrm{H}), 3.66(\mathrm{t}, J=5.9 \mathrm{~Hz}, 2 \mathrm{H}), 2.84(\mathrm{t}, J=7.3 \mathrm{~Hz}, 2 \mathrm{H}), 1.95(\mathrm{~s}, 3 \mathrm{H}), 1.83(\mathrm{~m}$, 2H), 1.26-1.22 (m, 3H), 1.09 (d, $J=7.2 \mathrm{~Hz}, 18 \mathrm{H}), 0.89$ (s, 9H), 0.04 (s, 6H). $-{ }^{13} \mathrm{C}$ NMR (100 
$\mathrm{MHz}, \mathrm{CDCl}_{3}$ ) $\delta 202.2$ (IV), 152.9 (IV), 136.0 (III), 62.3 (II), 33.7 (II), 27.8 (II), 26.0 (3C, I), 18.9 (6C, I), 18.4 (IV), 18.1 (3C, III), 12.1 (I), -5.3 (2C, I). (14c') IR (neat) 3030, 2980, 1685, 1650, 1250, 1100, 835, $715 \mathrm{~cm}^{-1}-{ }^{1} \mathrm{H}$ NMR (400 MHz, $\left.\mathrm{CDCl}_{3}\right) \delta 5.91$ (s, 1H), 5.67 (s, 1H), 3.63 (t, $J=4.4 \mathrm{~Hz}, 2 \mathrm{H}), 2.79$ (t, $J=7.4 \mathrm{~Hz}, 2 \mathrm{H}), 1.91$ (s, 2H), 1.83 (m, 2H), 1.26-1.22 (m, 3H), 1.04 (br s, 18H), 0.89 (s, 9H), 0.49 (s, 6H). $\left.-{ }^{13} \mathrm{C} \mathrm{NMR} \mathrm{(100} \mathrm{MHz,} \mathrm{CDCl}_{3}\right) \delta 201.7$ (IV), 148.1 (IV), 121.7 (II), 62.3 (II), 33.7 (II), 27.8 (II), 26.0 (3C, I), 18.7 (6C, I), 18.4 (IV), 18.1 (3C, III), 12.9 (II), -5.3 (2C, I).

Preparation of 2,2-bis(phenylseleno)propane. At room temperature, to a solution of phenylselenol (10 g, $63.7 \mathrm{mmol}, 2$ equiv) in $\mathrm{CHCl}_{3}$ (32 mL) was added to acetone (2.4 mL, 31.8 mmol, 1 equiv). After being cooled at $0{ }^{\circ} \mathrm{C}, \mathrm{Et}_{2} \mathrm{O} \cdot \mathrm{BF}_{3}(12.6 \mathrm{~mL}, 47.8 \mathrm{mmol}, 1.5$ equiv) was added to the reaction mixture. The temperature was warmed to room temperature, the mixture was stirred until TLC had indicated completion and diluted with $\mathrm{Et}_{2} \mathrm{O}$, washed successively with a $5 \%$ solution of aqueous $\mathrm{NaOH}$ and brine, dried over magnesium sulfate, filtered and concentrated in vacuo. 2,2-bis(phenylseleno)propane ${ }^{5}$ (9.23 g, 81\%) crystallized and was used without any further purification.

\section{4-[2-(Dimethylphenyl-silyl)-1-methyl-vinyl]-5-methyl-hex-4-en-1-ol (15a)}

1. To a cooled $\left(-78^{\circ} \mathrm{C}\right)$ solution of $5.19 \mathrm{~g}$ of 2,2-bis(phenylseleno)propane (14.5 mmol, 1.15 equiv) in $53 \mathrm{~mL}$ of THF were added dropwise $6.6 \mathrm{~mL}$ of $n$-butyllithium (solution $2.1 \mathrm{M}$ in pentane, $13.9 \mathrm{mmol}, 1.1$ equiv). After being stirred $15 \mathrm{~min}$ at this temperature, a solution of 4.76 $\mathrm{g}$ of compound 14a (12.6 mmol, 1.0 equiv) in $25 \mathrm{~mL}$ of THF was added. The mixture was warmed to room temperature. After being stirred for $1 \mathrm{~h}$, the solution was diluted with $\mathrm{Et}_{2} \mathrm{O}$ and the organic layer was washed successively with a saturated solution of $\mathrm{NH}_{4} \mathrm{Cl}$ and brine, dried over $\mathrm{MgSO}_{4}$, filtered and concentrated in vacuo. The crude oil was used directly in the elimination reaction without further purification.

2. Method A. To a solution of the preceding compound in $75 \mathrm{~mL}$ of $\mathrm{CH}_{2} \mathrm{Cl}_{2}$ were added 11.7 $\mathrm{mL}$ of triethylamine $\left(84.4 \mathrm{mmol}, 7.0\right.$ equiv). The mixture was cooled to $0^{\circ} \mathrm{C}$ and $1.8 \mathrm{~mL}$ of thionyle chloride (24.1 mmol, 2.0 equiv) were added. The solution was warmed to room temperature. After being stirred for $2 \mathrm{~h}$, the solution was then diluted with $\mathrm{Et}_{2} \mathrm{O}$ and the organic layer was washed with a saturated solution of $\mathrm{NH}_{4} \mathrm{Cl}$ and then, brine, dried over $\mathrm{MgSO}_{4}$, filtered and concentrated in vacuo. The crude oil was used directly in the elimination reaction without further purification.

3. To a cooled $\left(0^{\circ} \mathrm{C}\right)$ solution of the preceding compound in $170 \mathrm{~mL}$ of $\mathrm{THF}$ were added dropwise $13.9 \mathrm{~mL}$ of tetra-butylammonium fluoride (1M in THF, $13.9 \mathrm{mmol}, 1.2$ equiv). The solution was warmed to room temperature and stirred until completion of the reaction by TLC. The reaction mixture was extracted with $\mathrm{Et}_{2} \mathrm{O}$, washed with brine, dried over $\mathrm{MgSO}_{4}$, filtered and concentrated in vacuo. The residue was purified by flash chromatography (PE/EE 9/1) and furnished 15a (2.89 g, 82\% from 14a). IR (neat) 3540, 3030, 2920, 1560, 1230, 1090, $725 \mathrm{~cm}^{-1}-$ ${ }^{1} \mathrm{H}$ NMR (200 MHz, $\left.\mathrm{CDCl}_{3}\right) \delta$ 7.55-7.54 (m, 2H), 7.36-7.32 (m, 3H), $5.26(\mathrm{~s}, 1 \mathrm{H}), 3.63(\mathrm{t}, J=$ $6.4 \mathrm{~Hz}, 2 \mathrm{H}), 2.19$ (t, $J=7.4 \mathrm{~Hz}, 2 \mathrm{H}), 1.73$ (s, 3H), 1.63-1.55 (m, 8H), 0.37 (s, 6H). $-{ }^{13} \mathrm{C}$ NMR 
(50 MHz, $\mathrm{CDCl}_{3}$ ) $\delta 158.0$ (IV), 140.2 (IV), 139.8 (IV), 133.8 (2C, III), 128.8 (III), 127.84 (2C, III), 124.81 (III), 124.3 (IV), 62.9, (II) 31.5 (II), 27.2 (II), 22.3 (I), 21.9 (I), 19.7 (I), -0.8 (2C, I). - Anal. Calcd. for $\mathrm{C}_{18} \mathrm{H}_{28} \mathrm{OSi}$ : C, 74.94; H, 9.78. Found: C, 74.93; H, 9.82.

4-[2-(tert-Butyldimethylsilyl)-1-methyl-vinyl]-5-methyl-hex-4-en-1-ol (15b) was prepared following the procedure described for 15a. (1.66 g, 64\% from 14b). IR (neat) 3550, 3030, 2900, 1570, 1230, 1080, 810, $750 \mathrm{~cm}^{-1}-{ }^{1} \mathrm{H}$ NMR (400 MHz, $\left.\mathrm{CDCl}_{3}\right) \delta 5.09$ (s, 1H), $3.64(\mathrm{t}, J=6.4$ Hz, 2H), 2.18 (t, $J=7.4 \mathrm{~Hz}, 2 \mathrm{H}), 1.83$ (s, 3H), 1.70-1.55 (m, 8H), 0.93 (s, 9H), 0.11 (s, 6H). ${ }^{13} \mathrm{C} \mathrm{NMR}\left(100 \mathrm{MHz}, \mathrm{CDCl}_{3}\right) \delta 156.5$ (IV), 140.3 (IV), 135.6 (IV), 124.7 (III), 63.0 (II), 31.5 (II), 27.1 (II), 26.6 (3C, I), 25.7 (I), 21.9 (I), 19.6 (I), 17.4 (IV), -4.3 (2C, I). - Anal. Calcd. for $\mathrm{C}_{16} \mathrm{H}_{32} \mathrm{OSi}$ : C, 71.57; H, 12.01. Found: C, 71.42; H, 11.91.

\section{5-Methyl-4-[1-methyl-2-triisopropylsilyl)-vinyl]-hex-4-en-1-ol (15c)}

1. To a cooled $\left(-78^{\circ} \mathrm{C}\right)$ solution of 2,2-bis(methylseleno)propane (0.825 g, $3.76 \mathrm{mmol}, 1$ equiv) in THF (16 mL) were added dropwise $1.8 \mathrm{~mL}$ of $n$-butyllithium (solution $2.2 \mathrm{M}$ in hexane, 3.95 mmol, 1.05 equiv). After being stirred $1 \mathrm{~h}$ at this temperature, a solution of $1.5 \mathrm{~g}$ of $\mathbf{1 4 c / 1 4 c ^ { \prime }}$ (3.76 mmol, 1.0 equiv) in $11 \mathrm{~mL}$ of THF was added. The mixture was warmed to room temperature and then diluted with $\mathrm{Et}_{2} \mathrm{O}$. The organic layer was washed successively with a saturated solution of $\mathrm{NH}_{4} \mathrm{Cl}$ and brine, dried over $\mathrm{MgSO}_{4}$, filtered and concentrated in vacuo. The crude oil was used directly in the next step without further purification.

2. Method B. To a solution of the preceding compound in $20 \mathrm{~mL}$ of $\mathrm{CH}_{2} \mathrm{Cl}_{2}$ were added $3.83 \mathrm{~mL}$ of $\mathrm{NEt}_{3}$ (27.3 mmol, 7.25 equiv). The mixture was cooled to $0^{\circ} \mathrm{C}$ and a solution of $3.22 \mathrm{~g}$ of $\mathrm{PI}_{3}$ (9.26 mmol, 2.5 equiv) in $\mathrm{CH}_{2} \mathrm{Cl}_{2}(66 \mathrm{~mL})$ was added. After being stirred at $0{ }^{\circ} \mathrm{C}$, the solution was diluted with $\mathrm{Et}_{2} \mathrm{O}$, washed with a saturated solution of $\mathrm{NH}_{4} \mathrm{Cl}$ and then brine, dried over $\mathrm{MgSO}_{4}$, filtered and concentrated in vacuo. The crude oil was used directly in the next step without further purification.

3. The deprotection of the silylated ether followed the procedure described for 15a and furnished 15c (0.74 g, 63\%). IR (neat) 3550, 3030, 2900, 1580, 1250, 1080, $810 \mathrm{~cm}^{-1}-{ }^{1} \mathrm{H}$ NMR (400 $\left.\mathrm{MHz}, \mathrm{CDCl}_{3}\right) \delta 5.31(\mathrm{~s}, 1 \mathrm{H}), 3.64(\mathrm{t}, J=6.4 \mathrm{~Hz}, 2 \mathrm{H}), 2.20(\mathrm{t}, J=7.3 \mathrm{~Hz}, 2 \mathrm{H}), 1.82(\mathrm{~s}, 3 \mathrm{H}), 1.69$ $(\mathrm{s}, 6 \mathrm{H}), 1.65-1.61(\mathrm{~m}, 2 \mathrm{H}), 1.16(\mathrm{~m}, 3 \mathrm{H}), 1.08(\mathrm{~d}, J=6.4 \mathrm{~Hz}, 18 \mathrm{H})-{ }^{13} \mathrm{C} \mathrm{NMR}(100 \mathrm{MHz}$, $\mathrm{CDCl}_{3}$ ) $\delta 157.1$ (IV), 140.5 (IV), 123.9 (IV), 122.6, (III), 62.9, (II) 31.5 (II), 26.9 (II), 22.8 (I), 22.0 (I), 19.0 (6C, I),18.9 (I), 12.3 (3C, III), -0.8 (2C, I).

\section{4-[2-(dimethylphenylsilyl)-1-methyl-vinyl]-6-methyl-hept-1-yn-5-ene (2a)}

1. To a cooled $\left(0^{\circ} \mathrm{C}\right)$ solution of $2.83 \mathrm{~g}$ of $\mathbf{1 5 a}$ (9.8 mmol, 1 equiv) in $17 \mathrm{~mL}$ of $\mathrm{CH}_{2} \mathrm{Cl}_{2}$ were added $13.9 \mathrm{~mL}$ of DMSO (196.3 mmol, 20 equiv), $13.6 \mathrm{~mL}$ of triethylamine (98.2 mmol, 10 equiv) and $8.19 \mathrm{~g}$ of $\mathrm{SO}_{3} \bullet$ pyridine (58.9 mmol, 6 equiv). The mixture was stirred at room temperature until the reaction was completed by TLC. The solution was diluted with $\mathrm{Et}_{2} \mathrm{O}$, washed successively with a saturated solution of $\mathrm{NH}_{4} \mathrm{Cl}$ and brine, dried over $\mathrm{MgSO}_{4}$, filtered on a celite pad and concentrated. The crude oil was used in the next step without further purification. 
2. To a solution of the preceding compound ( $7.8 \mathrm{mmol}, 1$ equiv) in $80 \mathrm{~mL}$ of $\mathrm{MeOH}$ were added $2.14 \mathrm{~g}$ of $\mathrm{K}_{2} \mathrm{CO}_{3}$ (15.5 mmol, 2 equiv) and a solution of $1.79 \mathrm{~g}$ of dimethyl-1-diazo-2oxopropylphosphonate (9.3 mmol, 1.2 equiv ) in $40 \mathrm{~mL}$ of $\mathrm{MeOH}$. The mixture was stirred for $12 \mathrm{~h}$ at room temperature. The solution was diluted with $\mathrm{Et}_{2} \mathrm{O}$, washed with a saturated solution of $\mathrm{NH}_{4} \mathrm{Cl}$ and then brine, dried over $\mathrm{MgSO}_{4}$, filtered and concentrated in vacuo. The crude oil was purified by flash chromatography (pentane) and gave 2a (1.66 g, 60\% from 15a). IR (neat) 3380, 3020, 2980, 1590, 1420, 840, 730, $700 \mathrm{~cm}^{-1}-{ }^{1} \mathrm{H}$ NMR (200 MHz, $\left.\mathrm{CDCl}_{3}\right) \delta$ 7.62-7.59 (m, 2H), 7.41-7.38 (m, 3H), 5.34 (d, $J=1.0 \mathrm{~Hz}, 1 \mathrm{H}), 2.43$ (t, $J=7.9 \mathrm{~Hz}, 2 \mathrm{H}), 2.30-2.20$ (m, 2H), 1.98 (t, $J=2.5 \mathrm{~Hz}, 1 \mathrm{H}), 1.78$ (d, $J=1.0 \mathrm{~Hz}, 3 \mathrm{H}), 1.75$ (s, 3H), 1.73 (s, 3H), 0.43 (s, 6H). $-{ }^{13} \mathrm{C}$ NMR (50 MHz, $\mathrm{CDCl}_{3}$ ) $\delta 157.1$ (IV), 140.1 (IV), 138.6 (IV), 133.7 (2C, III), 128.8 (III), 127.8 (2C, III), 125.5 (III), 125.4 (IV), 84.8 (IV), 68.2 (II), 30.2, (II), 22.2 (I), 21.9 (I), 19.7 (I), 17.7 (II), -0.8 (2C, I) - HRMS Calcd for $\mathrm{C}_{19} \mathrm{H}_{26} \mathrm{Si}:\left(\mathrm{MH}^{+}\right)$283.180. Found 283.188.

tert-Butyl-(3-isopropylidene-2-methyl-hept-1-en-6-ynyl)-dimethyl-silane (2b) was prepared following the procedure for 2a. (0.775 g, 64\% from 15b). IR (neat) 2980, 2950, 2100, 1660, 1610, 1440, 1250, $930 \mathrm{~cm}^{-1}-{ }^{1} \mathrm{H}$ NMR (200 MHz, $\left.\mathrm{CDCl}_{3}\right) \delta 5.12$ (s, 1H), 2.37 (t, $J=7.6 \mathrm{~Hz}$, 2H), 2.19 (td, $J=7.6,2.7 \mathrm{~Hz}, 2 \mathrm{H}), 1.94$ (t, $J=2.8 \mathrm{~Hz}, 1 \mathrm{H}), 1.82$ (s, 3H), 1.70 (s, 3H), 1.66 (s, 3H), 0.91 (s, 9H), 0.12 (s, 6H). - $\left.{ }^{13} \mathrm{C} \mathrm{NMR} \mathrm{(50} \mathrm{MHz,} \mathrm{CDCl}\right) \delta 155.6$ (IV), 139.2 (IV), 125.3 (III), 125.0 (IV), 84.8 (IV), 68.0 (III), 30.1 (II), 26.6 (3C, I), 21.9 (2C, I), 19.7 (I), 17.7 (II), 17.4 (IV), -4.1 (2C, I). - Anal. Calcd. for $\mathrm{C}_{17} \mathrm{H}_{30} \mathrm{Si}$ : C, 77.98; H, 11.52. Found: C, 77.95; H, 11.33.

Triisopropyl-(3-isopropylidene-2-methyl-hept-1-en-6-ynyl)-silane (2c) same procedure as for 2a. (0.550 g, 80\% from 15c). IR (neat) 3310, 2980, 2950, 2100, 1660, 1610, 1440, 1260, $930 \mathrm{~cm}^{-}$

${ }^{1}-{ }^{1} \mathrm{H}$ NMR (400 MHz, $\left.\mathrm{CDCl}_{3}\right) \delta 5.05(\mathrm{~s}, 1 \mathrm{H}), 2.40-2.37(\mathrm{~m}, 2 \mathrm{H}), 2.24-2.20(\mathrm{~m}, 2 \mathrm{H}), 1.94(\mathrm{t}, J=$ $2.5 \mathrm{~Hz}, 1 \mathrm{H}), 1.83$ (s, 3H), 1.72 (s, 3H), 1.70 (s, 3H), 1.19-1.07 (m, 21H). $-{ }^{13} \mathrm{C}$ NMR (50 MHz, $\mathrm{CDCl}_{3}$ ) $\delta 156.3$ (IV), 139.4 (IV), 125.0 (IV), 123.3 (III), 84.8 (IV), 68.0 (III), 30.1 (II), 22.7 (I), 21.9 (I), 19.7 (I), 19.1 (6C, I), 17.7 (II), 12.3 (3C, III).

\section{Acknowledgements}

Financial support was provided by CNRS, Ministère de la Recherche and Institut Universitaire de France (Max Malacria is a member of IUF). M. Petit thanks Aventis-CNRS for his fellowship.

\section{References}

1. Kingston, D. G. I. Chem. Commun. 2001, 867 and pertinent references cited therein.

2. (a) Holton, R. A.; Kim, H. B.; Somoza, C.; Liang, F.; Biediger, R. J.; Boatman, P. D.; Shindo, M.; Smith, C. C.; Kim, S.; Nadizadeh, H.; Suzuki, Y.; Tao, C.; Vu, P.; Tang, S.; Zhang, P.; Murthi, K. K.; Gentile, L. N.; Liu, J. H. J. Am. Chem. Soc. 1994, 116, 1596 and 1599. (b) Nicolaou, K. C.; Yang, Z.; Liu, J. J.; Ueno, H.; Nantermet, P. G.; Guy, R. K.; 
Claiborne, C. F.; Renaud, J.; Couladouros, E. A.; Paulvannan, K.; Sorensen, E. J. Nature 1994, 367, 630. (c) Masters, J. J.; Link, J. T.; Snyder, L. B.; Young, W. B.; Danishefsky, S. J. Angew. Chem., Int. Ed. Engl. 1995, 34, 1723. (d) Wender, P. A.; Badham, N. F.; Conway, S. P.; Floreancig, P. E.; Glass, T. E.; Gränicher, C.; Houze, J. B.; Jänichen, J.; Lee, D.; Marquess, D. G.; McGrane, P. L.; Meng, W.; Natchus, M. G.; Paulsen, H.; Rawlins, D. B.; Satkofsky, J.; Shuker, A. J.; Sutton, J. C.; Taylor, R. E. J.; Tomooka, K. J. Am. Chem. Soc. 1997, 119, 2755 and 2757. (e) Kusama, H.; Hara, R.; Kawahara, S.; Nishimori, T.; Kashima, H.; Nakamura, N.; Morihira, K.; Kuwajima, I. J. Am. Chem. Soc. 2000, 122, 3811. (f) Mukaiyama, T.; Shiina, I.; Iwadare, H.; Saitoh, M.; Nishimura, T.; Ohkawa, N.; Sakoh, H.; Nishimura, K.; Tani, Y. I.; Hasegawa, M.; Yamada, K.; Saitoh, K. Chem. Eur. J. 1999, 5, 121.

3. (a) Aubert, C.; Buisine, O.; Petit, M.; Slowinski, F.; Malacria, M. Pure Appl. Chem. 1999, 71, 1463 and references therein. (b) Gandon, V.; Aubert, C.; Malacria, M. Chem. Commun. 2006, 2209. (c) Petit, M.; Aubert, C.; Malacria, M. Org. Lett. 2004, 6, 3937. (d) Petit, M.; Aubert, C.; Malacria, M. Tetrahedron 2006, 60, 10582.

4. (a) Petit, M.; Chouraqui, G.; Phansavath, P.; Aubert, C.; Malacria, M. Org. Lett. 2002, 4, 1027. (b) Chouraqui, G.; Petit, M.; Phansavath, P.; Aubert, C.; Malacria, M. Eur. J. Org. Chem. 2006, 1413.

5. Clarembeau, M.; Cravador, A.; Dumont, W.; Hevesi, L.; Krief, A.; Lucchetti, J.; Van Ende, D. Tetrahedron 1985, 41, 4793 and pertinent references cited therein.

6. a) Gilloir, F.; Malacria, M. Tetrahedron Lett. 1992, 33, 3859. b) Le Bideau, F.; Gilloir, F.; Nilsson, Y.; Aubert, C.; Malacria, M. Tetrahedron 1996, 52, 7487.

7. (a) Li, L. H.; Wang, D.; Chan, T. H. Tetrahedron Lett. 1991, 32, 2879. (b) Schlosser, M. J. Organomet. Chem. 1967, 8, 9.

8. Mancuso, A. J.; Huang, S. L.; Swern, D. J. Org. Chem. 1978, 43, 2480.

9. Knochel, P.; Singer, R. D. Chem. Rev. 1993, 93, 2117

10. Negishi, E-I.; Valente, L. F.; Kobayashi, M. J. Am. Chem. Soc. 1980, 102, 3298.

11. (a) Luccheti, J.; Remion, J.; Krief, A. C. R. Hebd. Seances Acad. Sci. Ser. C 1979, 288, 553.

(b) Lucchetti, J.; Krief, A. Tetrahedron Lett. 1981, 22, 1623.

12. Rubenstein, S. M.; Williams, R. M. J. Org. Chem. 1995, 60, 7215.

13. Bonnert, R. V.; Jenkins, P. R. J. Chem. Soc., Perkin Trans. 1 1989, 413.

14. Krief, A.; Halazy, S. J. Chem. Soc., Chem. Commun. 1979, 1136.

15. Parikh, J. R.; Von Doering, W. E. J. Am. Chem. Soc. 1967, 89, 5505.

16. (a) Ohira, S. Synth. Comm. 1989, 19, 561. (b) Müller, S.; Liepold, B.; Roth, G. J.; Bestmann, H. J. Synlett 1996, 521.

17. Still, W. C.; Khan, M.; Mitra, A. J. J. Org. Chem. 1978, 43, 2423. 